\title{
CONTOS DE FADAS E A FORMAÇÃO \\ DE VALORES MORAIS: PROJEÇÃO ḐO BEM E DO MAL NA LITERATURA INFANTIL
}

\author{
AMANDA COELHO DE ARAGÃO* \\ GABRIELA BALEEIRO DE ASSIS** \\ JÉSSICA MAYARA DA SILVA GONÇALVES*** \\ DENISE D'AURIA-TARDELI****
}

\begin{abstract}
RESUMO
O presente trabalho tem por objetivo principal analisar e discorrer sobre a importância dos contos de fadas para a formação moral nas crianças por meio das projeções sobre o bem e o mal. Para a realização deste artigo foram estudados autores como, por exemplo, Bruno Bettelheim, Piaget, Coelho, entre outros, bem como analisados três contos de fadas e seus principais personagens, no que se refere ao perfil ético e mensagem moral das histórias: Rumpelstiltskin, Alice No País Das Maravilhas e Peter Pan e Wendy. Verificou-se na conclusão que as discussões teóricas foram satisfatórias para a compreensão da importância de se trabalhar com histórias desde a mais tenra infância. Esta pesquisa nos possibilitou confirmar nosso questionamento inicial e refletir sobre as hipóteses.
\end{abstract}

Palavras-chave: Contos de fadas. Moral. Projeção simbólica. Infância.

\begin{abstract}
The main objective of this study is to analyze on the importance of fairy tales for the moral development in children through projections of ethical Good or Evil. For the accomplishment of this article we studied authors like, for example, Bruno Bettelheim,
\end{abstract}

\footnotetext{
* Formanda 2018 do curso de Pedagogia - UMESP.

** Formanda 2018 do curso de Pedagogia - UMESP.

*** Formanda 2018 do curso de Pedagogia - UMESP.

**** Professora orientadora da pesquisa - Trabalho de Conclusão de Curso.
} 
Piaget, Coelho, among others, as well as analyzed three fairy tales and their main characters, regarding the ethical profile and moral message of stories: Rumpelstiltskin, Alice In Wonderland and Peter Pan and Wendy. It was found in the conclusion that the discussions were satisfactory for the understanding of the importance of working with stories from the earliest childhood. This research enabled us to confirm our initial questioning and reflect on the hypotheses.

Keywords: Fairy tales. Moral. Symbolic projection. Childhood.

\section{INTRODUÇÃO}

A prática da contação de histórias é algo habitual no cotidiano das crianças, tanto nas escolas como em casa; porém os contos de fadas, por várias vezes, são vistos como passatempos, sem grande significado para muitos pais e professores. Para as crianças tais historietas possuem significativa importância, uma vez que encontram orientação intuitiva para resolver algumas situações do seu dia a dia, assimilando a ideia da existência do bem e do mal. Segundo Bruno Bettelheim (1980, p. 18), "as escolhas das crianças são baseadas não tanto no certo versus o errado, mas sobre quem desperta sua simpatia e quem incita sua antipatia", e assim, criando projeções e se identificando com personagens, vão construindo valores.

Por meio dessa mágica que o conto produz obtém-se consolo, esperança, coragem e diversos outros significados ocultos. Os contos de fadas, aos quais se referiu Bettelheim (1980, p. 64), "permitem à criança desenvolver aquele sentimento de confiança na vida que ela necessita para crer em si mesma", para conseguir assim encarar a vida com todas as suas dificuldades.

Sabe-se que a maturidade do ser humano se dá pelo desenvolvimento psicológico, independentemente da idade cronológica, e a busca pelo significado das coisas e do mundo em que vivemos é um passo importante nesse processo. Essa procura se inicia na infância, mas de maneira irracional. É necessário considerar também que para o infante conseguir criar elos de relacionamentos é necessário que ele entenda a si próprio e aos outros com quem 
convive, dando significado ao mundo, entendendo os motivos de sua existência, dos seus sentimentos e desejos.

Ao abordar essa temática Bettelheim (1980) explica que a literatura infantil possui grande influência nessa busca pelo autoconhecimento, na medida em que auxilia na compreensão da criança sobre o significado da vida. As histórias devem estimular a imaginação e ajudar nesse processo de entendimento, bem como nas resoluções de problemas internos mais complexos e desconhecidos, dando importância para eles.

Os contos dirigidos a esse público se baseiam em problemas existenciais, escritos de maneira breve e simples para que a criança entenda sem maiores problemas. Neles, o mal é tão presente quanto o bem, pois isso faz parte de todos nós, seres humanos. Porém, nas histórias, essa questão é bem dividida para que se compreenda da melhor forma possível onde cada um se encaixa, quais as características, as consequências e as soluções para cada um.

O psicólogo reforça que

As figuras nos contos de fadas não são ambivalentes - não são boas e más ao mesmo tempo, como somos todos na realidade. Mas dado que a polarização domina a mente da criança, também domina os contos de fadas. Uma pessoa é boa ou má, sem meio termo [...] (BETTELHEIM, 1980, p. 17).

Estar dentro de um mundo de fantasia não é prejudicial à criança, muito pelo contrário, é algo de notável importância para a construção de valores. Nos contos é possível analisar que em todo final da história o herói volta vitorioso à realidade, algo que realmente acontece com a criança, que termina a história voltando para o seu mundo com as forças renovadas. Como cita o estudioso (1980),

A criança intuitivamente compreende que, embora essas histórias sejam irreais, não são falsas; que ao mesmo tempo em que os fatos narrados não acontecem na vida real, 
podem ocorrer como uma experiência interna e de desenvolvimento pessoal. (BETTELHEIM, 1980, p.90).

Experimentar a fantasia dos contos de fadas é uma maneira de transcender a infância. Os novos desafios pelos quais a criança passa para alcançar a maturidade são cheios de desapontamentos, não sendo possível muitas vezes superar isso sozinha, sem ajuda de algum elemento. Essas narrativas são essenciais nesse processo, pois elas dão esperança de um futuro melhor e feliz. Assim, Bettelheim (1980) entende que as frustrações da criança lhe são insuportáveis e os contos as tornam toleráveis. Dito por outras palavras, por mais que a fantasia seja irreal os sentimentos futuros são verdadeiros e, além disso, a criança para de se desenvolver caso não tiver esperanças e bons pensamentos sobre o seu futuro.

Nessa mesma perspectiva, Fanny Abramovich chama atenção para o ato de que o infante precisa acreditar na magia para se sentir protegido do mal; assim como "os adultos bem crescidos andam com seus amuletos, com suas fitas de pedidos e desejos, invocam proteção daquelas nos quais creem, realizam seus pequenos ritos para que nada de mal aconteça a sua casa, etc." (ABRAMOVICH, 1997, p. 130).

Ademais, os contos de fadas proporcionam às crianças a oportunidade de conhecer um mundo repleto de novidades, de uma maneira simples e delicada. Tais historietas encorajam o sentimento de superação por conta dos finais felizes e, segundo o Referencial Curricular Nacional para a e Educação Infantil - RNCEI (1998, p. 16), as crianças "começam a perceber que sabem lidar com a realidade, que conseguem respostas positivas, fato que lhes dá segurança e que contribui para a construção de sua identidade".

Com a experiência das autoras deste artigo em escolas de educação infantil e baseado em suas percepções de que os contos de fadas fazem parte da vida escolar e são um dos gêneros preferidos das crianças - as pesquisadoras avaliam também que apesar desse modelo de literatura ser explorado há anos pela mídia por meio de textos, músicas, desenhos, séries, filmes e outras 
mídias -, este estudo pretende compreender a perda gradativa de importância dessa categoria de literatura nas práticas docentes, uma vez que ela é vista somente como um passatempo, distração para os alunos ou com o foco somente na alfabetização.

\section{MÉTODO}

O resgate dos contos de fadas na educação infantil gerou o seguinte problema de pesquisa: ao se depararem com contos de fadas que despertam tamanha identificação em todas as pessoas, as crianças poderiam ser influenciadas em sua formação a ponto de realizarem uma projeção dos fundamentos do bem e do mal transmitidos pelos personagens?

Como hipótese, podemos destacar que os contos de fadas não são vistos como um elemento importante na construção do aprendizado moral infantil, pois ainda existe certo olhar indevido que desvaloriza o gênero, tendo em vista que esse tipo de literatura nas escolas muitas vezes possui apenas função paradidática ou lúdica. Gostaríamos ainda de chamar a atenção para o aprendizado emocional e para a construção da visão de mundo, que a criança desenvolve a partir dos contos.

Nessa linha de raciocínio recorremos a Patrícia Corsino (2009), segundo a qual

Ler o mundo, ouvir histórias são fatores que influenciam na formação do leitor, uma vez que a formação do leitor se inicia nas suas primeiras leituras de mundo, na prática de ouvir histórias narradas oralmente ou a partir de textos escritos, na elaboração de significados e na descoberta de que as marcas impressas produzem linguagem. (2009, p. 57).

Os contos de fadas auxiliam na tarefa de construção da personalidade infantil, pois mais do que em qualquer outro tipo de narrativa encontramos diversos sentimentos que as crianças possuem, como: o amor, os medos, as carências materiais ou pessoais, as perdas e também as qualidades ou os defeitos que os personagens principais possuem, apresentando o conceito de que todo ser humano carrega em si coisas boas e ruins e de que forma lidamos com isso. Na percepção de Nelly Coelho (2000), 
os contos infantis, como a própria literatura, se tornam arte que "Funde os sonhos e a vida prática, o imaginário e o real, os ideais e sua possível/impossível realização...” (COELHO, 2000, p. 27).

O desenvolvimento desse trabalho de pesquisa foi definido tendo em vista o objetivo de refletir e investigar três contos de fadas e suas intencionalidades, sendo eles: Rumpelstiltskin, Aventuras de Alice no País das Maravilhas e Peter Pan e Wendy, buscando o significado e a origem da moralidade nestes relatos para entender as identificações e projeções no contexto infantil a partir da visão de mundo dos alunos, bem como compreender a relevância da inserção da literatura no universo infantil.

\section{DISCUSSÃO}

\section{O Anão Saltador - Rumpelstiltskin}

Escolhemos para tal tarefa o conto alemão popularizado pelos irmãos Grimm em 1812 intitulado "O anão saltador", mais conhecido pela figura de seu vilão Rumpelstiltskin. A narrativa traz a história de um moleiro que queria impressionar o rei, pois tinha o objetivo de fazê-lo casar com a sua filha e, para isso, o pobre operador de moinhos mente e diz que sua linda filha é capaz de fiar palha e transformá-la em ouro. O monarca, fascinado com a história, chama a moça, fecha-a numa torre com palha e uma roda de fiar e exige que ela transforme a palha em ouro durante três noites, ou será executada. A pobre moça já tinha perdido toda a esperança, pois sabia que não conseguiria fazer tal ato quando, magicamente aparece um duende no quarto em que está trancada e transforma toda a palha em ouro em troca do seu colar. Na noite seguinte, faz a troca com o seu anel. $\mathrm{Na}$ última noite, a moça já não possuía mais nada para dar ao gnomo e ele então transforma a palha em ouro, mas em troca pede o primeiro filho que ela desse à luz.

Vendo todo aquele ouro, o rei fica impressionado e decide casar-se com ela, mas quando nasce o primeiro filho do casal o duende retorna para exigir o seu pagamento. A rainha, assustada, oferece-lhe toda a sua riqueza, porém o duende recusa. Após muita insistência por parte da soberana, ele faz um novo trato: se ela conseguisse adivinhar o seu nome em três dias ele 
a deixaria ficar com a criança. No primeiro dia ela falhou, não acertou seu nome, mas antes da segunda noite o seu mensageiro ouve o duende saltando à volta de uma fogueira e cantando uma música onde ele dizia seu nome: Rumpelstiltskin. Então, no terceiro dia o espírito retorna para encontrar a rainha e ela revela o nome dele. Assim, o gnomo perde o seu trato. Depois disso Rumpelstiltskin foge zangado e nunca mais regressa.

Os irmãos Grimm trazem lições de moral ao fim de suas histórias e esse conto mostra a importância da honestidade. Aparecem diversos temas recorrentes, como as três provas, a tarefa impossível, a troca de favores por interesse, e também nos traz reflexões sobre o papel da mulher na sociedade da época e a forma como ela se submetia ao poder patriarcal, tanto no seu casamento arranjado pelo pai, como tendo que se submeter às ordens do rei ou aos caprichos do duende. Para os irmãos Grimm, os contos possuem um papel social e se contextualizavam à época em que são escritos - aqueles que são maus sofrem castigos, enquanto os bondosos recebem recompensas.

Em face dessas considerações percebe-se que Coelho (2010) entende que as narrativas desenvolvidas pelos Irmãos Grimm têm base na oralidade passada de geração em geração, sendo essa a essência de seus contos.

Quadro 1 - Perfil ético dos personagens do conto Rumpelstiltskin

\begin{tabular}{|l|l|}
\hline \multicolumn{1}{|c|}{ Personagem } & \multicolumn{1}{c|}{ Perfil ético } \\
\hline Rumpelstiltskin & Egocêntrico, interesseiro, manipulador. \\
\hline Moleiro & Mentiroso, cruel, interesseiro. \\
\hline Filha do moleiro & Submissa, humilde. \\
\hline Rei & Ambicioso, controlador, prepotente. \\
\hline
\end{tabular}

Fonte: As autoras

O personagem Rumpelstiltskin, protagonista do conto, também é o antagonista, uma vez que suas atitudes não são 
vistas como boas. Na história, o gnomo aparece para ajudar a filha do moleiro que precisa transformar palha em ouro, porém desde o início do conto ele mostra seu perfil interesseiro, uma vez que só ajudaria a filha do operador de moinho se ganhasse em troca algo que lhe interessava - e se não recebesse na hora voltaria depois para cobrar.

Podemos perceber, ao longo do conto, que a principal característica de Rumpelstiltskin é o seu egocentrismo. Ele não consegue demonstrar empatia, ou seja, não consegue se colocar no lugar do outro porque está constantemente ocupado com o seu «eu» e com os seus próprios interesses. Egoísta, porque pensa só em si, ou, pelo menos, pensa em si mesmo em primeiro lugar. Esse atributo, na visão de Piaget (2005), é natural nas crianças que se encontram na segunda infância (entre os $3 \mathrm{e}$ 6 anos), posto que nessa idade os infantes não são capazes de entender que os outros indivíduos possuem crenças, opiniões e pensamentos diferentes dos seus.

Já no que diz respeito à abrangência do egocentrismo no âmbito cognitivo - na maneira de raciocinar - esse psicólogo (2005) destaca a distinção entre o egocentrismo ontológico e o egocentrismo lógico. A diferença entre eles é que no egocentrismo ontológico há confusão entre o ego e mundo exterior, e no egocentrismo lógico, entre o pensamento próprio e o pensamento dos outros. Vê-se que Piaget (2005) apresenta o egocentrismo ontológico como o realismo do pensamento, no qual pode haver falta de clareza entre o subjetivo o objetivo. A criança passa a ter a compreensão do ser como fundamental para os acontecimentos do mundo físico, acreditando assim que os seres humanos são o centro de todas as coisas, principalmente das motivações psicológicas. Já no egocentrismo lógico há apenas analogias do particular para seu próprio mundo privado, sem reconhecimento de um princípio. "[o indivíduo] é, pois, egocêntrico sem sabê-lo e a consciência do seu egocentrismo atenuaria ou eliminaria esse egocentrismo" (PIAGET, 2005, p. 79). Assim como o personagem, o infante pensa apenas no seu particular, sem preocupações com o outro.

O moleiro é o pai da jovem moça, que, muito vaidoso e querendo encantar o rei diz que sua filha consegue transformar 
palha em ouro. Ser mentiroso é a sua principal característica e, como sabemos, a mentira é um mecanismo de defesa e se situa mais especificamente nas tomadas de decisão - a mentira é uma proteção da integridade do ego. $\mathrm{Na}$ infância essa característica pode ser vista como uma proteção na disputa contra o adulto, imponente, todo-poderoso, assim como o moleiro via o rei, mas que devido às suas limitações acredita que seja mais fácil igualar-se a ele. Ou seja, se sente inferior e, por meio da mentira pode se tornar o que quiser diante do adulto. Já na perspectiva de Corso e Corso (2006), "contar pequenas lorotas e ludibriar os adultos é um ato de independência, de perceber a limitação desses em controlá-lo" (p. 221).

Nesta história a filha do moleiro aparece como o "bem" no conto, a heroína, e torcemos para que ela consiga descobrir o nome do duende que deseja levar seu filho. Esse ângulo é também abordado por Betthelheim, que esclarece:

$\mathrm{O}$ conto de fadas começa com o herói à mercê dos que o desprezam e às suas habilidades, que o tratam mal ou mesmo ameaçam sua vida, como faz a rainha malvada em Branca de Neve. À medida em que a estória se desenrola, o herói é frequentemente forçado a depender de amigos que o ajudam: criaturas do mundo subterrâneo como os anões em Branca de Neve [...]. Quando o conto termina, o herói dominou todas as provas e apesar delas, ele permaneceu fiel a si próprio, ou, ao passar por elas exitosamente, adquiriu sua egoicidade verdadeira [...]. Nos contos de fadas, à diferença dos mitos, a vitória não é sobre os outros, mas apenas sobre si mesmo e sobre a vileza. Se nos dizem algo sobre o governo destes reis e rainhas, é que reinaram com sabedoria, pacificamente, e que viveram felizes. É nisto que deveria consistir a maturidade: uma pessoa a se governar sabiamente, e, como consequência, vivendo feliz. (BETTHELHEIM, 1980, p.159).

A figura do rei não é claramente situada como um personagem mau, mas no início da história notamos que ele é ganancioso e prepotente, uma vez que passa a exigir muito trabalho da jovem moça, e quanto mais tem o ouro, mais o quer. Tranca a jovem em um quarto exigindo que ela transforme a palha em ouro. Podemos perceber que o monarca se sente superior aos outros. 
Concluindo, nesse conto dos irmãos Grimm podemos ter uma mensagem moral ao fim da saga que traz a importância da honestidade e que não se deve "cantar vitória" antes da hora.

\begin{tabular}{|l|l|}
\hline Conto & Mensagem principal \\
\hline Rumpeltiltskin & $\begin{array}{l}\text { Nessa história percebemos a importância da generosi- } \\
\text { dade e que o egoísmo não resolve nada, uma vez que o } \\
\text { personagem que tentou tirar vantagem da pobre moça, } \\
\text { acabou o conto sem nada. }\end{array}$ \\
\hline
\end{tabular}

\section{Aventuras de Alice no País das Maravilhas}

O segundo conto escolhido é uma ruptura no mundo das histórias infantis, onde os valores morais foram deixados de lado para se trabalhar o crescimento e amadurecimento de uma forma divertida. É o caso do conto "As Aventuras de Alice no País das Maravilhas", de Lewis Carroll, que narra a história da menina Alice que num determinado momento está impaciente e entediada, assentada ao lado de sua irmã, que por sua se concentra na leitura de um livro. Na tentativa de arranjar alguma coisa para fazer Alice percebe um coelho branco com um relógio de bolso. Intrigada, corre atrás do coelho, mas subitamente, cai dentro da toca do pequeno animal: o portal para o "País das Maravilhas". No fundo do extenso buraco a protagonista se depara com diversas portas e uma chave que seria a correta para apenas uma delas. Alice bebe um líquido que a faz reduzir de estatura. Já pequenina, consegue passar pela porta e descobre um jardim. Mas o que ela nem imaginara é que havia entrado em um novo e diferente mundo. Um universo maravilhoso onde os animais falam. Podia se comunicar com rosas e outras figuras animadas. Nesse lugar conheceu uma lagarta que adorava dar conselhos, um exército formado por cartas de um baralho cuja ordens eram dadas pela Rainha de Copas, a quem deveria enfrentar. Conhece também um gato risonho, que aparecia e desaparecia, e um maluco chapeleiro. Ao retornar ao seu tamanho original e voltar à superfície, após vivenciar inúmeras aventuras naquele mundo fantasioso na ilustre companhia daqueles personagens é que a pequena Alice percebe que tudo não passara de um sonho. Ela estava de volta ao mundo real, havia acordado daquela viagem maravilhosa. 
Esse conto traz a imaginação de Alice como foco, transformando elementos do dia a dia em coisas e situações fantásticas, o que gerou enorme sucesso entre o público infantil, como afirma Coelho (2010):

Seu sucesso irrestrito entre os pequenos leitores decorreu, sem dúvida, de um fator decisivo: eles se sentiam identificados com as situações narradas; sentiam-se à vontade dentro de uma situação familiar e afetiva, que era subitamente penetrada pelo maravilhoso ou pelo mágico, com a mais absoluta naturalidade. Tal como Lewis Carroll fizera com Alice no País das Maravilhas, na Inglaterra de cinquenta anos antes, Monteiro Lobato o fazia no Brasil dos anos 20: fundia o Real e o Maravilhoso em uma única realidade. (2010, p. 249)

Abordaremos como essas informações são vistas pelas crianças, focando também em como a imagem da rainha que manda cortar as cabeças é associada a um simples baralho de cartas.

Quadro 2 - Perfil ético de personagens do conto Aventuras de Alice no País das Maravilhas

\begin{tabular}{|l|l|}
\hline \multicolumn{1}{|c|}{ Personagem } & \multicolumn{1}{c|}{ Perfil ético } \\
\hline Alice & Bondosa, educada, curiosa, sonhadora, destemida. \\
\hline Rainha de Copas & Autoritária, impulsiva, egocêntrica, inconstante. \\
\hline Chapeleiro Maluco & Carismático, excêntrico, lunático. \\
\hline Gato de Cheshire & Emblemático, conselheiro. \\
\hline Coelho Branco & Assustadiço, atrapalhado, apressado. \\
\hline Lagarta & Concisa, conselheira. \\
\hline
\end{tabular}

Fonte: As autoras

A protagonista do conto é Alice, uma garota extremamente inteligente, curiosa e corajosa o suficiente para enfrentar a sucessão de absurdos que vão acontecendo com ela ao longo da história. Os diálogos entre ela e as demais personagens elucidam como ocorre o convívio entre as crianças e os adultos, uma vez que por muitas vezes elas não são ouvidas e nem recebem 
atenção. Isso é legitimado por Corso e Corso (2006, p. 282) ao dizerem que:

De um jeito ou outro, os diálogos persistem somente enquanto a menina escuta e obedece, mas se interrompem assim que ela opina, solicita uma informação ou favor. Essa é uma experiência própria da infância que não raro se perpetua ao longo da vida: a maior parte dos nossos interlocutores não está interessada em escutar e ajudar. Todos querem falar, ser ouvidos, mas a triste constatação é que poucos realmente escutam. (CORSO e CORSO, 2006, p. 282).

Alice cai no buraco, motivada pela curiosidade, que é algo crucial no livro e também o que move qualquer criança. Vai parar em um mundo subterrâneo em um universo paralelo, que ao mesmo tempo é vinculado ao mundo da superfície, e a convivência desses dois mundos é fundamental na história.

Os conceitos de lógica e normalidade não estão ainda tão fixados nela como estão nos adultos, então a jovem enxerga os absurdos que acontecem no País das Maravilhas de uma forma diferente e, assim, convida o leitor a ver o nosso próprio mundo de outra forma, sem as comuns mensagens morais da maioria das histórias infantis. Alice se comporta como uma espécie de ponte entre o mundo de coisas absurdas e o mundo real, que é organizado, lógico e no qual supostamente tudo faz sentido, mas apesar disso, ela ainda é uma criança.

Esta tese é ressaltada pelo próprio romancista:

"Você está pensando em alguma coisa, minha cara, e isso a faz esquecer de falar. Neste instante não posso lhe dizer qual é a moral disso, mas vou lembrar daqui a pouquinho", disse a Duquesa. "Talvez não tenha nenhuma”, Alice atreveu-se a observar. (CARROLL, 2002, p. 87).

A questão de crescimento e amadurecimento é algo comum para todos quando se é criança e Alice, ao aparecer submersa 
nesse universo, enfrenta este fato, diminuindo e aumentando de tamanho repetidas vezes e precisa saber lidar com isso. Nesse ponto da discussão vamos aos estudos de Elsa Dias (2003), especialmente numa obra que apresenta a Teoria do Amadurecimento para Winnicott, para quem amadurecer depende de dois fatores: a tendência inata, que é a capacidade de mudança que nós já possuímos ao nascer, e o ambiente facilitador, que é acolhedor e propício a acalentar a transformação. Alice preservava em si essa tendência congênita, mas a negava devido ao fato de não possuir o ambiente facilitador.

Nos últimos capítulos da história, na cena do julgamento, está presente o ato de rebeldia de Alice, pois ao longo da narrativa ela vem se comportando como uma boa menina, educada e que atende a todas as normas de etiqueta, nunca revida a ninguém e é contestada o tempo todo. Quando é chegada a hora do jogo de cartas ela acaba por cometer o ato de fechar o livro, quando ela grita com a rainha e responde que não iria calar a boca e que ninguém se importava com eles, pois eram apenas um jogo de cartas, já voltando ao seu tamanho normal. A história chama a atenção das crianças pela atmosfera de sonho, de fantasia, pelo absurdo da trama.

Sobre os personagens podemos avaliar que a Rainha de Copas, figura que reina no País das Maravilhas, é uma personagem tirana, violenta, autoritária e dominante que constantemente ordena que cortem as cabeças de quem passa por seu caminho, de quem diz ou faz algo contra seu gosto - porém, essas ordens de decapitações nunca chegam a ser cumpridas. Alice inicialmente acredita que é boba e se assusta com ela. No final, no entanto, uma Alice de tamanho gigante é capaz de enfrentar o temperamento da rainha e suas ameaças.

O Chapeleiro Maluco aparece no conto quando Alice é temporariamente sua convidada para tomar chá, embora ela considere o evento como a festa do chá mais idiota que já participou. O personagem às vezes é rude com Alice e a provoca, se mostra bastante excêntrico com seus enigmas. O Chapeleiro Maluco se sente angustiado por ter recebido um castigo da Rainha de Copas e ter passado a não vivenciar as horas da 
forma habitual, por isso para ele sempre é a hora do chá. Os diferentes chapéus da personagem podem ser interpretados de acordo com o dicionário dos signos, de Lexicon (1998, p. 54), segundo o qual "o chapéu simboliza muitas vezes a cabeça ou os pensamentos; mudar de chapéu pode significar também mudar de ideia". Complementando esse pensamento, os estudiosos Jung e Von Franz (1968) afirmam que o ato de mudar de chapéu poderia alterar o pensamento de forma a oferecer ao indivíduo uma diferente visão de mundo.

O Gato de Cheshire é uma figura sorridente e se apresenta a Alice como um amigo nos momentos em que ela precisa saber o que fazer. É um personagem com quem ela consegue manter um diálogo mais tranquilo e também o único que realmente lhe dá ouvidos e explicações sobre determinadas coisas. Ele diz à jovem que todos no País das Maravilhas são loucos e ela inclusive também teria uma dose de loucura. É uma criatura sábia que pode desaparecer e reaparecer sempre que quiser, deixando às vezes apenas seu sorriso para trás. Dá conselhos, guiando-a em sua aventura, como uma espécie de consciência figurativa. Alice valoriza-o, mesmo sabendo que é um animal fantástico, por todos os ensinamentos transmitidos. Ao analisar esse ponto recorremos novamente a Jung (2011), que destaca a presença desses animais nas obras literárias infantis:

No conto de fadas deparamos frequentemente com o motivo dos animais prestativos. Estes comportam-se humanamente, falam língua humana e mostram uma sagacidade e um conhecimento superiores aos do homem. Neste caso pode-se dizer com razão que o arquétipo do espírito se exprime através da figura de um animal. (JUNG, 2011, p. 227).

Já o Coelho Branco é uma personagem que aparece logo no início do livro correndo apressado e dizendo que está atrasado, sempre conferindo as horas em seu relógio de bolso. Ele é que atrai Alice para o mundo subterrâneo e simboliza uma espécie de guia para ela. Ao contrário de Alice, o Coelho Branco possui muito medo, tanto de sua rainha e da própria Alice quanto das 
situações em que se encontra. Essa personagem foi responsável pelo primeiro contato de Alice com o País das Maravilhas, com esse espaço onírico.

Outra personagem, a lagarta, é de poucas palavras; não se mostra muito amigável e aparece fumando seu narguilé, sentada em um cogumelo, quando Alice a vê pela primeira vez. A pequena larva de imediato lança uma questão filosófica à jovem: "Quem é você?". Ao entrar nesse campo levamos a discussão a Chauí (2003):

[...] antes de querer conhecer a Natureza e antes de querer persuadir os outros, cada um deveria, primeiro e antes de tudo, conhecer-se a si mesmo. A expressão "conhece-te a ti mesmo" que estava gravada no pórtico do templo de Apolo, patrono grego da sabedoria, tornou-se a divisa de Sócrates. Por fazer do autoconhecimento ou do conhecimento que os homens têm de si mesmos a condição de todos os outros conhecimentos verdadeiros, é que se diz que o período socrático é antropológico, isto é, voltado para o conhecimento do homem, particularmente de seu espírito e de sua capacidade para conhecer a verdade. (CHAUÍ, 2003, p.43).

Com a missão de conhecermos a nós mesmos, entendemos que devemos partir de nossas concepções originais para poder ser e poder compreender. Assim, para nos descobrirmos enquanto existência deveríamos ter como princípio a análise do próprio "eu”, que é o que a lagarta vive a propor.

O desafio de Alice é crescer como uma pessoa forte e compassiva apesar das idiossincrasias das criaturas que ela conhece (seres que simbolizam o mundo adulto). Ela tem que aprender as regras de cada novo encontro, mas no final também deve manter um senso de justiça e desenvolver um senso de si mesma. 


\begin{tabular}{|l|l|}
\hline Conto & Mensagem principal \\
\hline Alice & $\begin{array}{l}\text { O valor central do conto é a coragem da protagonista, demon- } \\
\text { strada no decorrer de sua jornada ao desconhecido e que } \\
\text { consiste em dois aspectos: descobrir quem ela é e tornar-se } \\
\text { corajosa. }\end{array}$ \\
\hline
\end{tabular}

\section{Peter Pan e Wendy}

A terceira história abordada por este artigo é "Peter Pan e Wendy", na qual o objeto de estudo consiste na concepção de infância que nos é apresentada e a relação com o protagonista e antagonista. (Criado em 1902 pelo escritor escocês James Matthew Barrie a princípio para uma peça de teatro denominada "Peter Pan e Wendy" ou "O Menino Que Nunca Quis Crescer", o conto foi posteriormente adaptado a livro e publicado em 1911. Teve diversas adequações também ao cinema, sendo uma delas o clássico da Disney, de 1953.

A obra se tornou um marco da literatura infantil por ter sido escrita no fim da Belle Époque (período de grande desenvolvimento cultural cosmopolita vivenciado nos países ocidentais entre 1871 e o início da Primeira Guerra Mundial), restaurando as ideias de criação e de educação, marcando o nascimento de um novo mundo, o mundo da infância. O clássico infantil relata a história de um garoto que vive na Terra do Nunca com os meninos perdidos. A Terra do Nunca é o sonho de muitas crianças: uma ilha cheia de piratas, índios, sereias, fadas e monstros, e os pequenos que chegam lá nunca crescem. Peter e os meninos perdidos vivem sem pais e não há garotas na ilha, até que Peter leva Wendy e seus irmãos, João e Miguel, para a Terra do Nunca. Lá, Wendy passa a cuidar de Peter e dos meninos perdidos e vivem diversas aventuras, precisando aturar o ciúme da fada Sininho, grande amiga e fiel escudeira de Peter, e enfrentar os ataques do terrível arqui-inimigo de Peter Pan, o Capitão Gancho, sendo ele e sua tripulação os únicos adultos da Terra do Nunca.

O motivo pelo qual Peter Pan decide fugir é que na noite anterior à sua fuga, ele presencia uma discussão de seus pais sobre suas futuras responsabilidades e o que eles (pais) esperavam 
de seu futuro. Esta ideia reforça as mudanças culturais do final do século XIX, quando o próprio conceito de infância sofre alterações significativas, sendo completamente diferenciado do contexto do mundo adulto.

Os estudiosos da psicanálise nas histórias infantis, Diana e Mário Corso explicam:

Peter Pan não se recusa a crescer apenas porque ser criança é bom, na verdade, ele se nega a realizar esses papéis todos [impostos pelos pais]. É como um bebê que aprende a dizer não e prazerosamente descobre que tem poder para pôr um limite no assédio e nas demandas de que é objeto, dizendo "não" a tudo que lhe é solicitado. Por isso, a Terra do Nunca pode ser também o refúgio dos que não querem ser médicos, advogados, modelos, corredores de Fórmula 1, artistas ou jogadores de futebol famosos, dos que se recusam a empreender a corrida pela realização dos sonhos dos pais. (CORSO e CORSO, 2006, p. 231).

A escolha desse conto para nossa investigação se deu por causa da relação de Peter Pan com o Capitão James Hook (Capitão James Gancho), posto que o jovem tem receio de crescer e o Gancho e sua tripulação são os únicos adultos da Terra do Nunca e representam perigo para Peter e os meninos perdidos.

O capitão Gancho representa o mundo adulto, e daí vem o indesejável. Este personagem se preocupa com o crocodilo que lhe arrancou o punho e o relógio, destacando o seu medo quanto ao tempo. $\mathrm{O}$ mundo adulto exige produção, responsabilidade com o trabalho e o sustento diário, criando a tensão diária. Todos morrerão algum dia, porém Gancho recusa o tempo, a idade e a morte porque evita o crocodilo.

James Matthew Barrie captura também o conflito universal entre crianças e adultos. Os crescidos, com o tempo e com o cotidiano, se esquecem das aventuras e do imaginário infantil. Uma criança, entretanto, vê o mundo com olhos imaturos e inocentes. Suas vidas se passam em torno da aventura, dos seus sonhos e dos seus sentimentos. 
Ao analisar a temática, as investigadoras Regina Zilberman e Ligia Cademartori Magalhães esclarecem que

[...] não é a saída para o mundo da fantasia que coloca o herói perante o mundo, mas sua volta; o primeiro movimento leva o protagonista ao encontro de si mesmo - esta é sua grande aventura, a qual lhe permitirá enfrentar o contexto circundante, confiando em si ou conformado com sua falta de poder. Em razão disto, a fantasia configura a condição de funcionamento do gênero, pois este impõe um modelo narrativo que se desenvolve à medida que o protagonista abandona o setor familiar e ingressa em horizontes sobrenaturais, voltando depois à posição primeira, agora mais experiente ou sábio. (ZILBERMAN e MAGALHÃES, 1982, p. 27-28).

Vê-se que Peter Pan, como a maioria dos personagens bons das histórias de aventura, apresenta ingredientes básicos, é um herói e convive com o desconhecido e um vilão cruel que simboliza grande perigo. Todos esses elementos - principalmente aqueles que tornam Peter um herói e Gancho o vilão, bem como as aventuras que o garoto vence apesar das dificuldade e se torna mais grandioso do que Gancho - têm importância na formação moral infantil.

Quadro 3 - Perfil ético de personagens do conto Peter Pan e Wendy

\begin{tabular}{|l|l|}
\hline & \multicolumn{1}{|c|}{ Perfil ético } \\
\hline Peter Pan & Irresponsável, inconsequente, exibicionista, puro. \\
\hline Gancho & Temido, medroso, invejoso. \\
\hline Wendy & Responsável, amadurecida, sedutora. \\
\hline Sininho (fada) & Ciumenta, leal, irritada, apaixonada. \\
\hline Meninos perdidos & Impulsivos, puros, desregrados, rejeitados. \\
\hline
\end{tabular}

Fonte: As autoras 
Peter Pan é um marco da literatura infantil e, ao restaurar a ideia de criação e educação, marca o nascimento de um novo lugar, o mundo da infância, no qual quando nasce uma criança do seu primeiro riso inocente nasce também uma fada. Nesse espaço perder a sombra é algo normal.

Gerações anteriores foram expostas às dificuldades "No mundo real as pessoas são expostas às dificuldades e às responsabilidades da vida adulta, mas no conto uma nova mudança de atitude criou uma expectativa de que a vida de uma criança deveria ser de inocência e de dependência - tanto é que no livro Peter convida Wendy ...”) e às responsabilidades da vida adulta, mas uma nova mudança de atitude criou uma expectativa de que a vida de uma criança deveria ser de inocência e de dependência, tanto que no livro o fato de que Peter convida Wendy para Terra do Nunca e se estabelece então a relação de mãe e cuidadora dele e dos meninos perdidos, sem malícia alguma da parte dele. Peter quer alguém para cuidar e ler/contar histórias para eles, mostrando que não queria um relacionamento mas apenas uma substituta de mãe.

Outras características marcantes dessa geração: ser diligente no trabalho, respeitar autoridades e regras, ter a convicção de que "nada se alcança sem muito sacrifício", coisa simplesmente inexistente em relação à obra, visto que Peter Pan em si é um personagem que age, de fato, como uma criança: é divertido, destemido e despreocupado, se irrita facilmente quando contrariado, é presunçoso, egocêntrico e bem cruel, às vezes. Ele e os outros meninos formam um grupo bem bagunceiro e estão sempre dispostos a participar de desafios e brincadeiras (violentas, na maioria das vezes).

Zilberman e Magalhães entendem que

[...] Peter Pan sintetiza os dois aspectos: ele é uma força natural - um pássaro, devido à capacidade de voar; a brisa, invisível e rebelde; o próprio deus Pan, símbolo da vida selvagem e do instinto. Ao mesmo tempo, o menino opta por não crescer, cabendo-lhe sintetizar a infância. (ZILBERMAN e MAGALHÃES, 1982, P. 54) 
As condições de vida de muitas crianças da classe trabalhadora no final do século XIX eram inaceitáveis. Reconstruir a sociedade foi o grande motivador, a grande missão dos jovens daquele tempo. Refazer a estrutura social e econômica direcionou boa parte deles para a formação de suas próprias famílias, para a educação dos filhos.

Os ideais humanitários da época postulavam que crianças deveriam ser protegidas contra danos físicos, da corrupção moral, das responsabilidades da vida adulta e que toda criança deveria ter a oportunidade de viver uma infância saudável e afetuosa:

Os que se resignam a crescer também se conformam à sua futura mediocridade; por mais que façam, serão fadados a ser mais um dos adultos que ficam devendo diante de tudo o que poderiam ter sido na vida. No nosso tempo, crescer está associado a perder, não há mais tanto prestígio na condição adulta. (CORSO e CORSO, 2006, p. 231).

Percebe-se que a irresponsabilidade contida em Peter é a chave de permanecer criança, visto que o ato de crescer é algo assustador para ele e seus amigos. Era assim também que Barrie (2012, p. 8) enfrentava sua vida, segundo ele próprio: “A melhor coisa do mundo é ser criança, a segunda melhor coisa do mundo é escrever sobre criança, melhor ainda porque o livro e a infância contida nele se tornam eterna".

$O$ vilão Gancho é o temido capitão que usa trajes de um fidalgo inglês e comanda um navio chamado Jolly Roger, ancorado em uma baía da Terra do Nunca, e traz no lugar de sua mão um gancho que ele usa para amedrontar os demais personagens. Esta figura carrega aspectos antagônicos ao nosso protagonista, ademais de perseguir a juventude de Pan, pois é o seu oposto: velho, ranzinza e sempre tentando impedir a renovação. Mas é também desesperado pelo poder, tem uma grande preocupação com os bons modos como todo estudante de internato britânico, pois foi educado para seguir regras e decoros. Assim Capitão Gancho e seus capangas são apontados em certos momentos do enredo, como seres desprezíveis, indignos de qualquer respeito. 
E apesar de querer demonstrar o contrário, Peter se incomodava bastante com a presença dos adultos na ilha. Nas palavras do autor:

Mas é claro que Peter se importava sim, e muito. Sentiu tanto ódio dos adultos, que estavam estragando tudo como sempre, que assim que entrou em sua árvore respirou de propósito bem rápido e curto, fazendo mais ou menos cinco respirações por segundo. Peter fez isso porque, segundo diz um ditado da Terra do Nunca, sempre que você respira, um adulto morre. (BARRIE, 2012, p. 150).

Os piratas descritos neste conto apresentam as mesmas características de outros em histórias tradicionais, como A Ilha do Tesouro. O capitão Gancho é cruel e vingativo; seus homens obedecem às suas ordens sem questionar, mas ele é também um vilão dotado de medos que são sempre ironizados no decorrer da narrativa, como o medo de sangue, da perda dos bons modos, além do pavor de que o tique-taque um dia cesse e o tempo acabe para ele, como destacam Corso e Corso (2006):

Embora grande adversário de Gancho seja Peter Pan, seu maior medo era o crocodilo que já comera sua mão. Talvez esse também seja o medo de Peter, afinal, o que significa esse crocodilo que faz tique taque permanentemente? Sabemos que ele engoliu um relógio, simbolicamente ele mesmo pode ser o relógio, ou melhor, o tempo, afinal é ele quem come a carne de todos os que ficam velhos. (p. 240).

Já Wendy, é a personagem mais madura e responsável da história de Peter Pan. Filha mais velha do casal Darling, ela se orgulha de sua infância e gosta de contar histórias de fantasia. $\mathrm{Na}$ noite em que ela é separada dos irmãos, ganha seu próprio quarto para que deixe as fantasias da infância para começar a apreender as responsabilidades femininas de uma mulher adulta do século XX, sente certa repugnância em crescer. Nessa noite Peter aparece para levá-la junto com os irmãos para a Terra do Nunca, onde permanecem criança por um tempo indeterminado 
e, ironicamente, com as experiências que trazem à tona seu lado mais adulto ela se mostra muito responsável, sedutora e madura.

Peter e os meninos perdidos esperam que Wendy se torne sua "mãe", um pedido que ela timidamente aceita, realizando várias tarefas domésticas para eles e lhes contando histórias. Ela fica encantada com a ideia de "brincar de mãe" - lembrando que ela também é uma personagem criada no início do século $\mathrm{XX}$, que obviamente não pensava em um plano de carreira para si, visto que estava sendo criada para casar e ter filhos, sendo assim mãe e dona de casa, expressando o desejo de todas as meninas de sua época.

Wendy passa portanto a ser o anima (parte feminina do homem) no ambiente criado por Peter para si e para os Meninos Perdidos, pois é ela quem traz a individuação e os ajuda no desenvolvimento da personalidade quando os chama para irem embora com ela e com os seus irmãos da Terra do Nunca. Isso afirma "o elemento feminino que resolve o problema, que entra em cena e decide a favor de uma ou de outra parte" (VON FRANZ, 2005, p. 73). Ela, então, começa a aceitar as virtudes de crescer e percebe que recusar a crescer é abdicar do novo e a viver sem seus pais - ideia que não a agrada, mas infelizmente, Peter se recusa a deixar a Terra do Nunca, fazendo com que uma parte dela fique ligada a ele.

Posteriormente foram incorporadas algumas modificações da peça na qual Wendy cresceu, casou-se e teve uma filha, Jane. Quando Peter retorna à procura de Wendy ele conhece a nova garotinha e a leva para a Terra do Nunca com a permissão de Wendy, que deixa a filha ir esperando que essa faça a mesma escolha. O mesmo ocorre com a filha de Jane, a neta de Wendy, Margarete.

O criador de Peter Pan e Wendy revela que

toda vez que chega a hora de fazer a faxina de primavera a não ser quando ele esquece -, Peter vem buscar Margaret e a leva para a Terra do Nunca, onde ela lhe conta histórias sobre si mesma, as quais ele ouve com grande atenção. Quando Margarete crescer, ela vai ter uma filha, e vai ser a vez dela de ser mãe de Peter. (BARRIE, 2012, p. 220). 
Percebemos que uma parte do animus de Wendy ainda permanece presa na infância, com sua filha e neta repetindo sua jornada à Terra do Nunca.

Dotadas de extrema beleza, as fadas que nascem do primeiro riso de uma criança devem muito de sua descrição ao autor J.M. Barrie. Presentes na literatura mundial, mas nunca tendo sido citadas com tanto carinho e detalhes quanto por Barrie, as fadas se apresentam como seres pequenos com asas, cercadas de luz e que podem morrer a qualquer momento se não acreditarmos nelas ou apenas por dizer "fadas não existem", eliminando assim um ser tão mítico e cheio de conhecimento. Desse modo, conhecemos a parceira de aventura mais leal de Peter, a fada Sininho, uma beldade loira que usa um vestido verde, se comunica com o tilintar de sinos de ouro e seu pó de fada faz com que crianças voem.

A Terra do Nunca é um lugar de lembranças, que oferece a todas as crianças as mais reais aventuras de suas vidas durante o sono. Mas é também um espaço de esquecimento, pois os que vivem ali permanentemente já foram esquecidos por suas famílias. Prova disso é o chefe dos meninos perdidos, que tentou retornar para casa em determinado momento, mas encontrou a janela fechada com grades e em sua cama havia outra criança, o que queria dizer de que seus pais já o haviam esquecido e substituído.

Esses meninos impulsivos, brincalhões, desregrados que mostram as crianças em sua forma mais pura, sofreram abandono e, como Peter, preferem esquecer e viver suas aventuras na Terra do Nunca. No fim, nem eles nem Peter podem ser julgados, pois, como bem lembra Comte-Sponville, "O sofrimento é um mal, e seria um engano ver nele uma redenção" (COMTE-SPONVILLE, 2009, p. 29).

\begin{tabular}{|l|l|}
\hline Conto & Mensagem principal \\
\hline Peter e Wendy & $\begin{array}{l}\text { Compreendendo que nada é completo, o conto de fadas } \\
\text { nos propõe a busca da pureza e a busca das virtudes ao } \\
\text { considerar o complexo humano em suas diversas facetas. }\end{array}$ \\
\hline
\end{tabular}




\section{CONSIDERAÇÕES FINAIS}

Ao fim da análise desses contos podemos perceber que além do simbolismo que estas histórias têm para as crianças, mesmo que ainda inconscientemente, é de extrema importância que sejam trabalhadas em sala de aula.

Essas narrativas, segundo Corso e Corso (2006), trazem elementos e acontecimentos da vida real, até mesmo conflitos que as crianças passam internamente, e por meio dessas histórias o aluno encontra modelos e segurança para a resolução de problemas. E ainda: os contos de fadas refletem a sociedade e o contexto em que vivemos, possibilitando uma reflexão para que possamos tomar decisões em situações ou percalços pelos quais passamos.

Com o término deste estudo percebemos que a leitura/ utilização dos contos em sala de aula pode ser algo muito significativo e prazeroso, além de possibilitar aos educandos refletir sobre diferentes situações da vida real. Ao levar essa iniciativa/prática para a sala de aula a escola vai ao encontro das Referenciais Nacionais Curriculares de Educação Infantil (1998), segundo as quais as instituições educacionais devem incentivar o aluno a pensar de forma reflexiva. Isso é algo que deve ser estimulado desde a pequena infância, respeitando as individualidades dos alunos.

Observamos também que as histórias aqui analisadas possuem um elo entre si, na medida da existência do lado bom e do lado mau, em que o bem sempre luta para vencer o mal. Nesses contos cada personagem busca um significado para suas vidas.

Retomando o nosso problema de pesquisa, verificamos que ao se depararem com os contos de fadas as crianças tendem a realizar reflexões, buscando a projeção dos mesmos nas ações do dia a dia, seja por meio de jogos, brincadeiras, fantasias de faz de conta ou por outras maneiras que podem ser introduzidas pelos professores. Assim, como ressalta Coelho (2010),

[...] o que a criança encontra nos contos de fada são, na verdade, categorias de valor que são perenes. Impossível 
prescindirmos de juízos valorativos: a vida humana, desde as origens, tem-se pautado por eles. O que muda é apenas o conteúdo rotulado de "bom" ou "mau", "certo" ou "errado" (COELHO, 2010, p. 34, grifos do autor).

Influenciadas em sua formação moral pelos fundamentos de bem e mal expressos em cada nova geração nos contos infantis transmitidos pelos personagens, as crianças os compreendem e incorporam em suas escolhas pessoais.

\section{REFERÊNCIAS}

ABRAMOVICH, F. Literatura Infantil: gostosuras e bobices. São Paulo: Scipione, 1997.

BARRIE, J. M. Peter Pan. Tradução: Julia Romeu. São Paulo: Zahar, 2012.

BETTElheim, B. A Psicanálise dos Contos de Fadas. Rio de Janeiro: Paz e Terra, 2007.

BRASIL. Referencial Curricular Nacional para a Educação Infantil (RCNEI) BRASIL. LEI N 9394/96. Diretrizes e Bases da Educação Nacional. Setembro de 1996. Brasília: Editora do Brasil, 1998.

CARroll, L. Aventuras de Alice no País das Maravilhas e Através do Espelho. Introdução e notas: Martin Gardner. Tradução: Maria Luíza X. de A. Borges. Rio de Janeiro: Zahar, 2002.

CHAUÍ, M., Convite à Filosofia. 13. ed. São Paulo: Ática, 2003.

COELHO, N. N. Literatura Infantil: Teoria, Análise, Didática. 1. ed. São Paulo: Moderna, 2000.

COELHO, N. N. Panorama Histórico da Literatura infantil/juvenil: das origens indoeuropeias ao Brasil contemporâneo. 5.ed. São Paulo: Amarilys, 2010.

COMTE-SPONVILlE, A. Pequeno Tratado das Grandes Virtudes. São Paulo: Martins Fontes, 1999. Reeditado em 2000. Disponível em: <http:// christianrocha.files.wordpress.com/2008/12/pequeno-tratado-das-grandes-virtudes.pdf>. Acesso em: 26. out. 2018.

CORSINO, P. Prática Educativa da Língua Portuguesa na Educação Infantil. Curitiba: IESDE Brasil, 2009.

CORSO, D; CORSO, M. Fadas no Divã. Porto Alegre: Artmed, 2006.

DIAS, E. O. A teoria do amadurecimento de D. W. Winnicott. Rio de Janeiro: Imago, 2003.

JUNG, C.G. Os arquétipos e o inconsciente coletivo. In: Obras Completas de C. G. Jung, vol. IX/1. Petrópolis: Vozes, 2011.

JUNG, C.G.; VON FRANZ, M.-L. (Ed.). Man and his symbols. Random House LLC, 1968. 
LEXICON, H. Dicionário de símbolos. São Paulo: Cultrix, 1998.

PIAGET, J. O desenvolvimento do pensamento. Equilibração das estruturas cognitivas (Figueiredo, A., Trad.). Lisboa: Publicações Dom Quixote, 2005. VON FRANZ, M. L. A interpretação dos contos de fada. 5. ed. São Paulo: Paulus, 2005.

ZILBERMAN, R.; MAGALHÃES, L. C. Literatura infantil: autoritarismo e emancipação. São Paulo: Ática, 1982.

146 Cadernos de Educação, v.17, n. 35, jul.-dez. 2018 